\title{
Evaluation of discovery learning in the field of cultural heritage
}

\author{
aantamarina-Campos, Virginia, ${ }^{\mathrm{b}}$ Carabal-Montagud, María-Ángeles, ${ }^{\mathrm{c}}$ Esgueva- \\ Lopez, Maria-Victoria, ${ }^{\mathrm{c}}$ Taroncher-Ballestero, José-Manuel \\ a - bepartamento de Conservación y Restauración de Bienes Culturales, 'Departamento de Dibujo, \\ dEducation, research, culture and sports counseling. Valencian Generalitat
}

\begin{abstract}
The theory of constructivist learning, also known as discovery learning is a learning methodology in which the student instead of receiving the content passively, discovers the concepts and their relationships and rearranges them to adapt them to their cognitive scheme. This method transforms students into protagonists of the learning process, who develop research skills through an inductive method. Therefore, it is configured as an ideal tool to situate students in a sociocultural dimension, favoring the understanding of the appearance and socio-historical construction of the concept of cultural heritage taking into account the transformations of late modernity and the new current situation defined as globalization This work aims to assess the degree of acceptance and satisfaction of students, in relation to the process of implementation of learning by discovery, through anonymous surveys in which the different strategies and tools used in this methodology are analyzed, with the aim of improving and optimize the design of the programming.
\end{abstract}

Keywords: discovery learning, inductive reasoning, inductive thinking, inductive strategy, guided discovery, evaluation, cultural heritage, EICEAFA-Reality.

\section{Introduction}

The new conception of cultural heritage and its recent transformations, requires rethinking an important reflection on the new patrimonial action models. Tourism, globalization and the patrimonialisation of new cultural elements require the revision and proposal of new methods of intervention, in which sociocultural aspects are contemplated, their values of use, formal and symbolic / identity (Santamarina Campos, Carabal Montagud, De Miguel Molina, \& De Miguel Molina, 2016). 
This change in the perception and management of cultural heritage has meant a profound transformation in the design of conservation and restoration projects. This fact opens the way to the acceptance of an intersubjective participation and a consideration of the broader discipline, which transcends the limits of the object and compilation study, and gives greater prominence to the subjects receiving and the different processes of meaning, conceiving this professional activity to Starting from "their social uses, not from a mere defensive attitude, of simple rescue, but with a more complex vision of how society appropriates its history, it can involve new sectors. It does not have to be reduced to a matter of the specialists of the past [...] " (García Canclini, 1993).

In relation to the above, moving from the object of restoration to the subject that gives a set of values, as a reason to study implies the need to raise, from the analysis and reflection, a process of deconstruction, reinterpretation and redefinition of previous criteria solidly settled in the field of conservation and restoration of cultural assets (such as objectivity, authenticity, truth, materiality, ...) by others that pave the way to the path of subjectivity.

This supposes the need to discover in the student a critical and creative position regarding the importance of the social construction of heritage and its intervention, which should be enriched, questioned and rethought throughout his professional career. Therefore, in eminently theoretical subjects, in which the main objective is to provide an approach to cultural heritage from a social perspective (Santamarina Campos et al., 2016), it is necessary to implement a methodology that allows generating an active and social learning process, in which students build new ideas or concepts based on current knowledge. In this way, the student can select the information, originate hypotheses, and make decisions in the process of integrating experiences in their existing mental constructions.

The theory of constructivist learning, also known as learning by discovery is a learning methodology in which the student instead of receiving the content passively, discovers the concepts and their relationships and rearranges them to adapt them to their cognitive scheme. This method transforms students into protagonists of the learning process, who develop research skills through an inductive method (Zarza C., 2009). Therefore, it is configured as an ideal tool to situate students in a sociocultural dimension, favoring the understanding of the appearance and socio-historical construction of the concept of cultural heritage taking into account the transformations of late modernity and the new current situation defined as globalization (Santamarina Campos et al., 2016).

For this reason, the implementation of learning by discovery has been carried out in the following theoretical matters:

- Management of intangible heritage (33848). Optional. Number of ECTS: 4.5. Number of students: 35. Department of Conservation and Restoration of Cultural Property, Master's Degree in Conservation and Restoration of Cultural Property. 
- Development, management and direction of restoration projects. Optional. Number of ECTS: 4.5. Number of students: 35. Department of Conservation and Restoration of Cultural Property, Master's Degree in Conservation and Restoration of Cultural Property.

- History of the Conservation and Restoration of Cultural Property (33841). Optional. Number of ECTS: 4. Number of students: 35. Department of Conservation and Restoration of Cultural Property, Master's Degree in Conservation and Restoration of Cultural Property.

These subjects offer an approach to cultural heritage and its management / intervention, in order to place the student in a sociocultural dimension that enriches the analysis and knowledge of the object to be intervened. The purpose of these subjects is to approach the student to:

- The most relevant aspects of cultural heritage in relation to different sociocultural contexts.

- The fundamental concepts of the restoration and patrimonial management practice from the different approaches: identity-symbolic, economic and political.

- Develop the ability to analyze, synthesize and evaluate the different aspects on which the notion of cultural heritage is built in the field of conservation, restoration and management.

- Appropriating heritage, assuming its role in conservation and professional training.

On the other hand, these subjects work the transversal competences of analysis and problem solving, innovation, creativity and entrepreneurship and teamwork and leadership, understanding and integration and critical thinking. For this reason, learning by discovery constitutes an ideal methodological tool to work on these competences and acquire the necessary levels of mastery (Table 1). 
Table 1. Linking Transversal Competencies with the fundamental principles of discovery learning. Source eleboración propia, based on (ICE, 2015) and (Bruner, 2006).

\begin{tabular}{|l|l|}
\hline \multicolumn{1}{|c|}{ Transversal Competences (ICE, 2015) } & $\begin{array}{l}\text { Linking with the fundamental principles } \\
\text { of discovery learning (Bruner, 2006) }\end{array}$ \\
\hline $\begin{array}{l}\text { Analyze and solve problems effectively, } \\
\text { identifying and defining the significant } \\
\text { elements that constitute them. }\end{array}$ & $\begin{array}{l}\text { The main objective of education must be } \\
\text { the ability to solve concrete problems and } \\
\text { practical application in real life. }\end{array}$ \\
\hline $\begin{array}{l}\text { Innovate to respond satisfactorily and in an } \\
\text { original way to personal, organizational } \\
\text { and social needs and demands with an } \\
\text { entrepreneurial attitude. }\end{array}$ & $\begin{array}{l}\text { Meaning is the product of creative } \\
\text { discovery and not the verbalization of } \\
\text { concepts. }\end{array}$ \\
\hline $\begin{array}{l}\text { Work and lead teams effectively to } \\
\text { achieve common goals, contributing to the } \\
\text { personal and professional development of } \\
\text { them. }\end{array}$ & $\begin{array}{l}\text { The discovery efficiently organizes what } \\
\text { has been learned for later use. }\end{array}$ \\
\hline $\begin{array}{l}\text { Demonstrate the understanding and } \\
\text { integration of knowledge both of one's } \\
\text { own specialization and in other broader } \\
\text { contexts. }\end{array}$ & $\begin{array}{l}\text { The real and most important knowledge is } \\
\text { the one learned by oneself. }\end{array}$ \\
$\begin{array}{l}\text { The discovery ensures the conservation of } \\
\text { information. }\end{array}$ \\
$\begin{array}{l}\text { Develop a critical thinking interested in } \\
\text { the foundations on which the ideas, actions } \\
\text { and judgments, both their own and those } \\
\text { of others, are based. }\end{array}$ & $\begin{array}{l}\text { The empowerment of students in creativity } \\
\text { and critical thinking should be prioritized. }\end{array}$ \\
\hline &
\end{tabular}

\section{Objectives}

The main objective of this proposal is to evaluate the degree of acceptance and satisfaction of students, in relation to the process of implementation of learning by discovery, through anonymous surveys in which the different strategies and tools used in this methodology are analyzed, with the aim of improving and optimizing the design of the programming of the subjects involved.

Therefore, the final objective will be for students to discover the transformations produced in cultural heritage in an active, constructive and collaborative way. In this way, based on 
the material and tools provided by the teachers, what Bruner defines as scaffolding (Bruner, 2006), students can discover in a co-creative way the most complex and changing concepts that the field of cultural heritage presents.

Also, this experience is part of the Innovation and Educational Improvement Team (EICE) "The process of Teaching and Learning Outside the Classrooms - Reality Baths (EICEAFA-Reality)". The Innovation and Educational Quality Teams (EICE) are an initiative of the Vice-rectorate for Studies, Quality and Accreditation (VECA), with the support of the Institute of Education Sciences (ICE) and the Commission for the Evaluation and Followup of Innovation Projects and Educational Improvement (CESPIME) of the Universitat Politècnica de València

\section{Description of innovation development}

As indicated, the objective of the implementation of learning by discovery has been to modify the functions and the role of the teacher, which does not expose the content with full value, but rather the student is the one who acquires a large part of knowledge by itself (Baro, 2011), through its co-creative experience of discovery or reception of information. Thus, $85 \%$ of classroom time, is intended to perform practices in the classroom, with the aim is that the student discover in an active and collaborative way what you want to learn.

In this way the theoretical content of these subjects is structured on the basis of key questions, which pose problems to be solved, from which the students can get new ideas and the fundamental concepts of the subjects involved, based on the knowledge learned in the preceding sessions and matters.

For this, the theory is presented as questions, which students must solve collaboratively, with the help of the tools provided by the teacher. The questions are always resolved in groups of between 3 and 5 students, respecting parity. In each session, on a rotating basis, a group representative is assigned who is the one that exposes and defends the results of the question worked, so that there is a balanced and orderly participation of all the students throughout the semester. For each session a template is given to complete in group, A3 sheets or continuous paper, post-it, gometes and colored markers, to facilitate the collaborative work (Image 1 and 2), allow them to obtain models of more efficient and rich systems, by synthesizing different points of view, merging mental models (Santamarina, Carabal, de Miguel, \& de Miguel, 2018). In addition, the questions are accompanied by complementary material, such as press news, TV news, a film, a short film, a report, an article of research, a story or simply an image. In this way, from the delivered material, students should try to find the answer, analyzing the information provided that is always 
linked to contemporary and current issues. Once the practice is finished, each group presents its answers and a directed debate is opened, in order to lead and build the appropriate response among all. As a conclusion, the teacher presents some slides that synthesize the answer to the question posed, strengthening the most important aspects of the new concept acquired. In this way, through the answers of the key silver questions, the students construct in a directed way the theory linked and applied to contemporary issues.

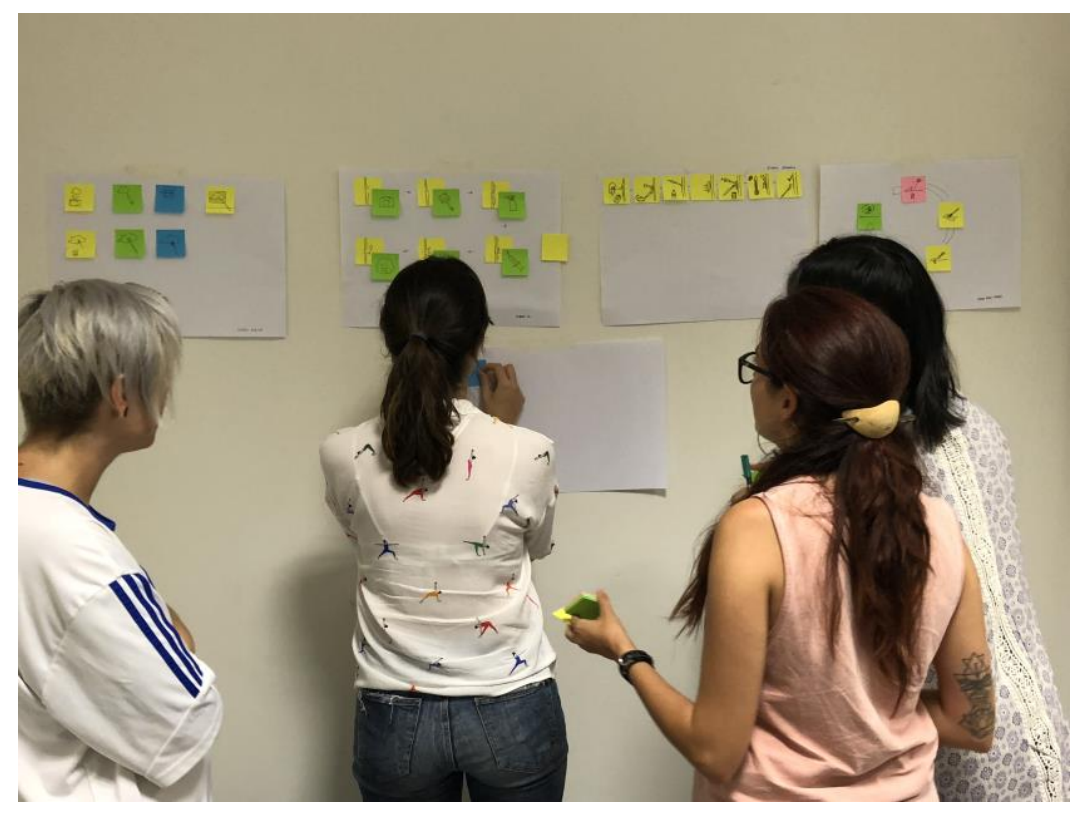

Image 1. Detail of a collaborative work session, in the subject Development, management and management of restoration projects. Source: Own photography, academic year 2018-2019. 


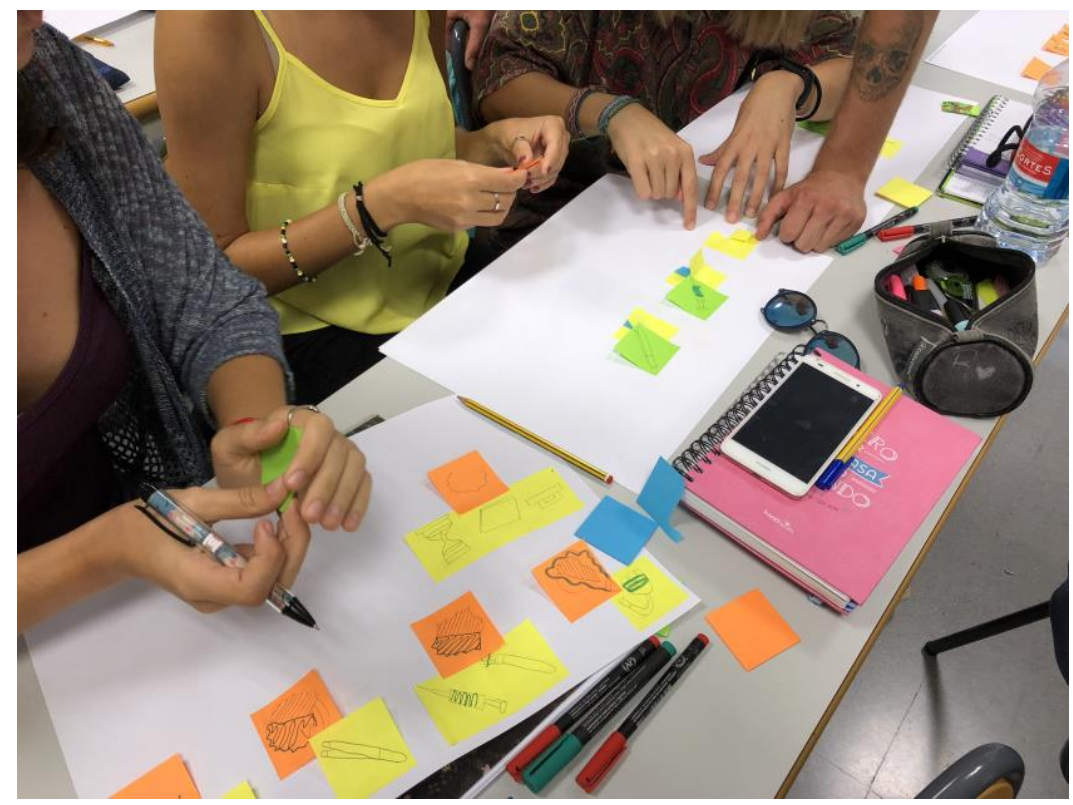

Image 2. Detail of a collaborative work session, in the subject Development, management and management of restoration projects. Source: Own photography, academic year 2018-2019.

\section{Results}

After completing the subjects in which the methodology of learning by discovery was implemented, students were asked to fill in an anonymous online survey, composed of 12 questions that analyzed the effect of using the different tools used to achieve learning. significant, focusing mainly on:

1. The use of real cases.

2. The use of photographs, press articles, audiovisual resources, TV programs, etc.

3. The use of movies or short films.

4. The use of reflective questions.

5. The realization of manipulative and collaborative practices.

The results of the surveys confirmed the great acceptance of this methodology by the students, obtaining a global average of the surveys of 4.35 out of 5 (table 2). 
Table 2. Result of satisfaction surveys in relation to the use of learning by discovery. The rating range was from 1 to 5 . There were 1 totally disagree and 5 totally disagree. Source: self made.

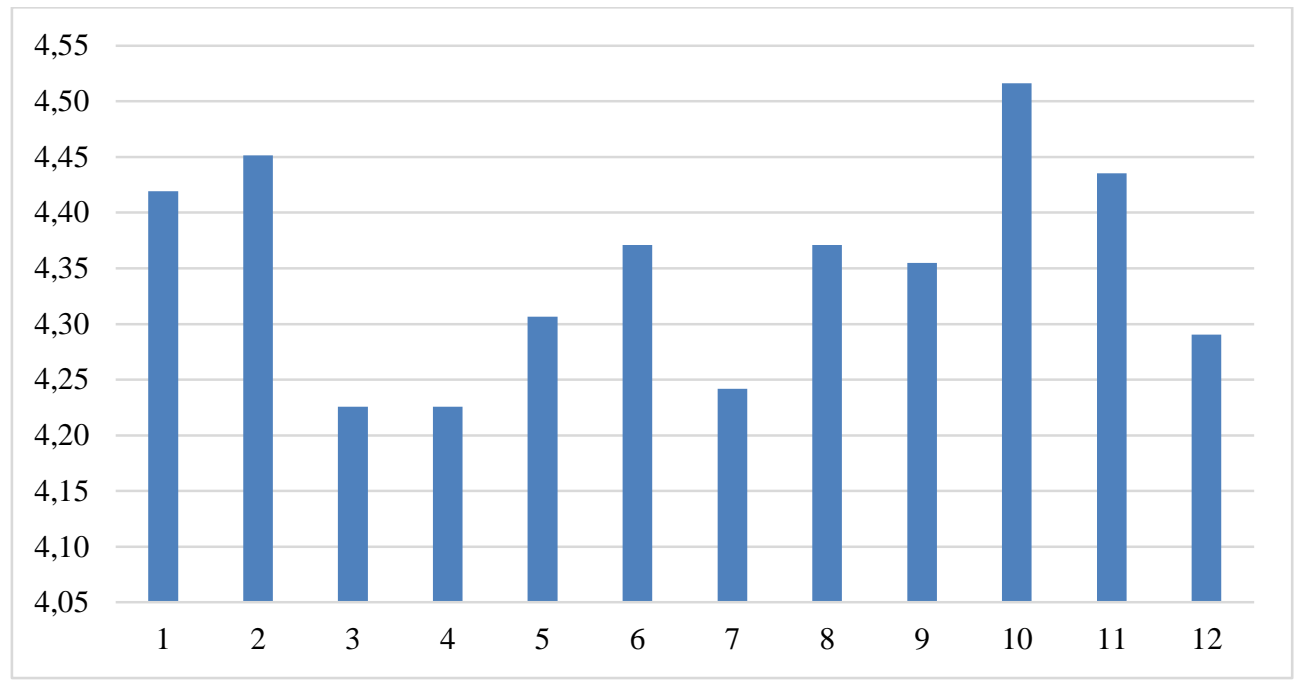

Both ask that they obtained a grade equal to or higher than 4.5, were related to degree of satisfaction in relation to use real cases through press articles, video clips, movies, etc., with the aim of internalizing knowledge, remember them more easily, and understand the theoretical explanation later.

\section{Conclusions}

The transformation of heritage has brought about a new focus in its management and intervention, which makes it necessary to incorporate aspects related to the symbolicidentity, political and economical dimension. Discovering in a co-creative way the most complex and changing concepts that the field of cultural heritage presents, is a fundamental process that motivates students to solve problems independently and cooperatively, with minimal support from the teacher.

On the other hand, learning by discovering, consolidates the fundamental concepts facilitating their management and promoting the independence of the students, facilitating the development of the final master's work and promoting a flexible and exploratory learning, expanding the fields of action. 
Learning through this method is relevant, and is evident in the presentations made by the students of final master projects that are presented in the Department of Conservation and Restoration of Cultural Property of the UPV, when applied in real cases that the students themselves transfer to the working world, promoting the research and innovation of the students and motivating them to present project proposals to public calls. In the academic year 2018-2019 there has been an increase of 20\% in the number of proposals for final works of subject or master that have been submitted after public calls or prizes. On the other hand, the level of satisfaction of the students with the use of this technique is evident in the results of the surveys, in which after the implementation of this tool they increase between 10 and $15 \%$ the final assessment.

\section{References}

Baro, A. (2011). METODOLOGÍAS ACTIVAS Y APRENDIZAJE POR DESCUBRIMIENTO. Revista Digital Innovación y Experiencia Educativa.

Bruner, J. S. (2006). In search of pedagogy Volume I: The selected works of Jerome Bruner, 19571978. In Search of Pedagogy Volume I: The Selected Works of Jerome Bruner, 1957-1978. https://doi.org/10.4324/9780203088609

García Canclini, N. (1993). El consumo cultural en España. Consejo Nacional para la Cultura y las Artes, Dirección General de Publicaciones. Retrieved from http://metacampus.udgvirtual.udg.mx/metacampus-liferayportlet/viewFile?id=15\&persistence=AVACursosPersistenceI7779

ICE. (2015). Proyecto de competencias transversalesUPV. Rúbricas. Retrieved from https://www.upv.es/entidades/ICE/info/U0724624.pdf

Santamarina Campos, V., Carabal Montagud, M. Á., De Miguel Molina, M., \& De Miguel Molina, B. (2016). La resoluciones de problemas a través de mapas conceptuales móviles cooperativos. In Libro de Actas IN-RED 2016 - II Congreso Nacional de Innovación Educativa y de Docencia en Red (pp. 442-456). Valencia: Universitat Politècnica València. https://doi.org/10.4995/INRED2016.2016.4338

Santamarina, V., Carabal, M. Á., de Miguel, M., \& de Miguel, B. (2018). Collaborative Visual Language for the Development of Innovative Ideas. EDULEARN18 Proceedings, 1(July), 535543. https://doi.org/10.21125/edulearn.2018.0216

Zarza C., O. (2009). Aprendizaje por descubrimiento. Innovación y Experiencias Educativas. https://doi.org/10.1016/0268-960X(92)90028-O 